\title{
Accidental falls in the elderly and their relation with functional capacity ${ }^{1}$
}

\author{
Jack Roberto Silva Fhon ${ }^{2}$ \\ Suzele Cristina Coelho Fabrício-Wehbe ${ }^{3}$ \\ Thais Ramos Pereira Vendruscolo ${ }^{4}$ \\ Renata Stackfleth ${ }^{5}$ \\ Sueli Marques ${ }^{6}$ \\ Rosalina Aparecida Partezani Rodrigues ${ }^{7}$
}

\begin{abstract}
Aim: This study aimed to determinate the prevalence of falls in the elderly and its relationship with the functional capacity. Method: This is an epidemiological and cross-sectional study; a two-stage cluster sample of 240 male and female subjects aged over 60 years was used. Data were collected from November 2010 to February 2011. The following questionnaires were used: socio-demographic profile, assessment of falls, Functional Independence Measure, Lawton and Brody Scale. Significance was set at 0.05 . To identify the occurrence of falls and their relation with functional capacity, the prevalence ratio and prevalence odds ratios were used, as well as multiple logistic regression. Results: Average age was 73.5 years $( \pm 8.4) ; 25 \% 80$ years or more, with preponderance of female gender; $48.8 \%$ attended school between $1-4$ years. The average was 1.33 falls ( \pm 0.472 ), with prevalence in women and elderly between 60 and 79 years old; the most frequently sites were the backyard and bathroom. Strong correlation between the level of functional independence and instrumental activities and age was found, but no relation between elderly victims of falls and the gender and age variables. Conclusion: Women who suffered falls related to functional independence were predominant, which can be prevented through elderly health promotion strategies, a policy that serves to offer living conditions to people in the aging process.
\end{abstract}

Descriptors: Aged; Accidental Falls; Activities of Daily Living; Cross Sectional Study.

\footnotetext{
${ }^{1}$ Supported by Programa de Estudante-Convênio de Pós-Graduação, CAPES/CNPq.

2 MSc, Professor, Escuela Académico Profesional de Enfermería, Universidad Privada Norbert Wiener, Peru.

3 PhD, Professor, Centro Universitário Barão de Mauá, Brazil.

${ }^{4}$ Master's student, Escola de Enfermagem de Ribeirão Preto, Universidade de São Paulo, WHO Collaborating Centre for Nursing Research Development, Brazil.

${ }^{5}$ Undergraduate student in Nursing, Escola de Enfermagem de Ribeirão Preto, Universidade de São Paulo, WHO Collaborating Centre for Nursing Research Development, Brazil.

${ }^{6} \mathrm{PhD}$, Professor, Escola de Enfermagem de Ribeirão Preto, Universidade de São Paulo, WHO Collaborating Centre for Nursing Research Development, Brazil.

7 PhD, Full Professor, Escola de Enfermagem de Ribeirão Preto, Universidade de São Paulo, WHO Collaborating Centre for Nursing Research Development, Brazil.
}

Corresponding Author: Jack Roberto Silva Fhon Universidad Privada Norbert Wiener.

Escuela Academico Profesional de Enfermería

Av. Arequipa, 440

Urbanización Santa Beatriz

01 Lima, Peru

E-mail: beto fhon@hotmail.com 


\section{Quedas em idosos e sua relação com a capacidade funcional}

Objetivo: determinar a prevalência de quedas em idosos e sua relação com a capacidade funcional. Método: trata-se de estudo epidemiológico transversal de base populacional, com uma amostra por conglomerado de duplo estágio de 240 sujeitos, com idade acima de 60 anos, de ambos os sexos, residentes em Ribeirão Preto, SP. Os dados foram coletados entre novembro de 2010 e fevereiro de 2011 e utilizaram-se os questionários: perfil social, avaliação de quedas, Medida de Independência Funcional e Escala de Lawton e Brody. Foi adotado o nível de significância de 0,05. Para a identificação da ocorrência das quedas e sua relação com a capacidade funcional, foram utilizadas razão de prevalência e de chances de prevalência e regressão logística múltipla. Resultados: a média de idade foi de 73,5 anos $( \pm 8,4), 25 \%$ com 80 anos ou mais, predomínio do sexo feminino; 48,8\% estudaram de 1 a 4 anos. Média de 1,33 quedas $( \pm 0,472)$; com maior prevalência em mulheres e idosos mais jovens; o local mais frequente foi o quintal e o banheiro. Houve forte correlação entre o nível de independência funcional e as atividades instrumentais com a idade, e não houve relação entre os idosos que sofreram queda e as variáveis sexo e idade. Conclusão: houve predomínio de mulheres que sofreram quedas relacionadas à independência funcional, podendo-se prevenir com estratégias de promoção à saúde ao idoso, política essa para oferecer condição de vida à pessoa no processo de envelhecer.

Descritores: Idoso; Acidentes por Quedas; Atividades Cotidianas; Estudos Transversais.

\section{Caídas en mayores y su relación con la capacidad funcional}

Objetivo: Determinar la superioridad de caídas en los mayores y su relación con la capacidad funcional. Método: Estudio epidemiológico transversal de base de la población, con una muestra por conglomerado de doble cursillo de 240 sujetos, con edad arriba de 60 años, de ambos los sexos, residentes en Ribeirão Preto. Los datos fueron colectados entre noviembre de 2010 y febrero de 2011 y se utilizaron los cuestionarios: perfil social, evaluación de caídas; Medida de Independencia Funcional y Escala de Lawton y Brody. Fue adoptado el nivel de significancia de 0,05. Para la identificación de la ocurrencia de las caídas y su relación con la capacidad funcional fueron utilizadas razón de superioridad y de chances de superioridad y regresión logística múltiple. Resultados: La media mayores fue de 73,5 años $( \pm 8,4), 25 \%$ con 80 años o más, predominio del sexo femenino; 48,8\% estudiaron durante 1 a 4 años. Media 1,33 caídas $( \pm 0,472)$; con mayor superioridad en mujeres y mayores más jóvenes; el local más frecuente fue el patio y el baño. Hubo fuerte correlación entre nivel de independencia funcional y las actividades instrumentales con la edad y no hubo relación entre los mayores que sufrieron caída y las variables sexo y edad. Conclusión: Hubo predominio de mujeres que sufrieron caídas relacionados a la independencia funcional, lo que puede ser prevenido con estrategias de promoción a la salud al mayores, política ésta para ofrecer condición de vida a la persona en el proceso de envejecer.

Descriptores: Adulto Mayor; Accidentes por Caídas; Actividades Cotidianas; Estudios Transversales.

\section{Introduction}

The growing increase of the elderly population all over the world and in Brazil represents a political, economic and social challenge, in view of this population group's new demands. 
In Brazil, according to estimates, in 2020, there will be 28.3 million people over 60 years of age, rising to approximately 64 million in 2050, showing the population growth in this age group ${ }^{(1)}$.

This panorama relates to a big discussion about incapacitating events and the need to maintain elderly people's autonomy and independence, that is, to mainly the basic and instrumental activities of daily living and be independent in one's functional capacity.

Functional capacity is defined as the ability to maintain the physical and mental activities the elderly needs, which means being able to live without help for basic and instrumental activities of daily living(2-3). Its commitment entails important implications for the elderly, their family, for the community and the health system, as disability brings about greater vulnerability and dependence in old age, thus contributing to reduce the elderly's well-being and quality of life.

Among disabilities, accidental falls among elderly people are highlighted, particularly in Brazilian and international studies, because they are considered events that directly affect their functional capacity ${ }^{(4)}$. A fall can be considered an unintentional and unexpected domestic accident in which the individual's body moves to a lower level than his/her original position, without the ability to correct in due time, conditioned by intrinsic (inherent to the elderly person) and extrinsic factors (related to the environment); it is the second cause of death by accidental and non-accidental injuries(5-6).

Consequences of falls can range from the most simple (like abrasions) to the most complex, like activity constraints, fear of falling syndrome and health problems, generating long-term care demands(6-7).

In the literature review, the theme falls versus dependence/independence has been hardly discussed in nursing, although the elderly health concept is considered related with functional capacity. Thus, through the application of the Katz Index and Lawton and Brody's scale to elderly people, one can assess whether the fall can cause a reduction in functional capacity for basic activities of daily living (BADLs) as well as for instrumental activities of daily living (IADLs), consequently losing their independence and affecting their autonomy and quality of life $\mathrm{e}^{(4,7-8)}$

In view of the increase in the elderly population, the impact a fall can cause in the lives of the elderly, family and society and the lack of research on this theme and its related factors, the aim of this study is to estimate the prevalence of falls in elderly people and their relation with functional capacity. In this respect, the following questions arise: Which are the most affected activities in elderly victims of falls? What was the elderly's dependence/independence level after the falls?

This study is justified to the extent that the number of elderly people in society is increasing and a consensus exists among researchers in the area that, in society, the preservation of one's functional capacity is one of the main aspects of the elderly health concept. Thus, this research covers a significant sample of elderly people living at home. Besides, the theme is considered one of the main priorities in the area and, hence, data can contribute to education in elderly health, family health, health team, including the nurse, responsible for comprehensive health care to the elderly. In this educative process, the nurse is responsible for evaluating the elderly's functional capacity, as the professional who will outline the care strategies for falls prevention. Hence, the main aim in this study is to estimate the prevalence of falls and their relation with functional capacity; the data can contribute to the elaboration of recommendations for fall and disability prevention in the elderly, highlighting that, often, these two circumstances may or may not take place jointly. The results can also support guidelines for the construction of public policies and health care programs for this population group.

\section{Method}

This cross-sectional research was developed in Ribeirão Preto, São Paulo State, Brazil.

The inclusion criteria were: elderly aged 60 years or older, male and female; living at home and scoring on the Mini-Mental State Examination $(\mathrm{MMSE})^{(9)}$. The predictive variable was the fall.

A two-stage cluster sample was determined. For the first stage, the census sector was considered as the sampling unit and, for the second, the individual over 60 years of age. A sample of 240 individuals was calculated, guaranteeing a maximum error of $6.3 \%$ at a $95 \%$ probability level. To reach $N=240,20$ out of 650 existing census sectors were drafted. The streets in the selected sectors were numbered, drafted and inserted in Statistical Package for the Social Sciences (SPSS) software, followed by a new draft of blocks in the selected streets.

Data were collected between November 2010 and February 2011; the interviewers visited the selected blocks clockwise until finding 12 elderly per sector in conditions to be included in the sample. 
The following instruments were used: structured script with questions to characterize the elderly's social profile (gender, age, marital status and years of education) and context of the falls, elaborated by members of the Geriatric and Gerontological Research Group (NUPEGG) at the University of São Paulo at Ribeirão Preto College of Nursing (EERP); Lawton and Brody's Instrumental Activities of Daily Living (IADL) scale, validated for the Brazilian context, was used to measure functional capacity and care demand(10). The score range of this scale goes from 7 (dependence) to 21 (independence). The Functional Independence Measure (FIM) score, translated and validated in Brazil(11), varies between 18 (total dependence) and 126 points (complete independence).

For data analysis, a worksheet was elaborated in Microsoft Excel ${ }^{\circledR}$ software, in which data were organized through the double-entry method, followed by validation. The data were imported into SPSS version 11.5 for descriptive statistical analysis. Quantitative variables were analyzed with the help of central trend (mean and median) and dispersion (standard deviation) measures, while proportions were used for categorical variables. Other specific tests were performed, including Student's t-test to compare means between the elderly group and Pearson's correlation test between the measures of interest. Significance was set at 0.05 . Association measures were calculated in contingency tables ( $X^{2}$, prevalence ratio and prevalence odds ratio). For the final analysis of the main outcome, multiple logistic regression was used, with the occurrence of the fall or not as the outcome and the following predictive variables: gender and age.

The project was forwarded to the Research Ethics Committee at the University of São Paulo-USP at Ribeirão Preto College of Nursing for evaluation and approval (Process No. 1169/2010). All subjects signed the Informed Consent Term.

\section{Results}

As observed, out of 240 elderly interviewees, $25 \%$ were 80 years or older, ranging from 60 to 94 years, with a mean age of 73.5 years and standard deviation $\pm 8.4 ; 62.9 \%$ were female; concerning marital status, $57.4 \%$ were married and $31.3 \%$ widowed; $48.8 \%$ had between one and four years of education and $14.6 \%$ were illiterate.

The prevalence of falls for the six months before the interview amounted to $33.3 \%$; most victims were female and considered young elderly (60 to 79 years), as shown in Table 1.

Table 1 - Prevalence of accidental falls in elderly living at home according to gender, young elderly and elder elderly. Ribeirão Preto, SP, Brazil, $2011(n=240)$

\begin{tabular}{|c|c|c|c|c|c|c|c|}
\hline \multirow{2}{*}{ Variables } & \multicolumn{2}{|c|}{ Falls (yes) } & \multicolumn{2}{|c|}{ Falls (no) } & \multirow{2}{*}{ Prevalence Ratio } & \multirow{2}{*}{$\begin{array}{l}\text { Prevalence odds } \\
\text { ratio }\end{array}$} & \multirow{2}{*}{$\mathbf{p}^{*}$} \\
\hline & $\mathbf{N}$ & $\%$ & $\mathbf{N}$ & $\%$ & & & \\
\hline \multicolumn{8}{|l|}{ Gender } \\
\hline Male & 25 & 31.25 & 64 & 40.0 & $0.682(0.386-1.204)$ & $0.771(0.520-1.143)$ & 0.186 \\
\hline Female & 55 & 68.75 & 96 & 60.0 & & & \\
\hline \multicolumn{8}{|l|}{ Age range } \\
\hline 60- 79 years & 54 & 67.5 & 126 & 78.75 & $0.560(0.307-1.023)$ & $0.692(0.480-0.998)$ & 0.058 \\
\hline 80 and over & 26 & 32.5 & 34 & 21.25 & & & \\
\hline
\end{tabular}

$* \mathrm{p}: \mathrm{X}^{2}$ test. Significance level $\alpha=0.05$

On average, 1.33 falls happened per elderly; the median was 1.0 and the standard deviation \pm 0.472 .

As for the number of falls, $25 \%$ were victims of one to two falls, $25.8 \%$ female and $23.6 \%$ male; $6.3 \%$ experienced between three and four falls in the previous six months, $8.6 \%$ of whom were female and $2.2 \%$ male; five or more falls happened to $2.1 \%, 2.0 \%$ of whom were female and $2.2 \%$ male.
Table 2 illustrates that the most reported sites for the fall events were: on the patio / backyard and in the bathroom.

Most falls in this group happened from the elderly's own height, followed by falls from the bed, and $12.5 \%$ needed hospitalization; the main consequences were excoriations and, to a lesser extent, sprains and strains. 
Table 2 - Accidental falls in the elderly living at home, according to gender, place of event, hospitalization, type of fall and consequences. Ribeirão Preto, SP, Brazil, $2011(n=80)$

\begin{tabular}{|c|c|c|c|c|c|c|}
\hline \multirow{2}{*}{ Variables } & \multicolumn{2}{|c|}{ Male } & \multicolumn{2}{|c|}{ Female } & \multicolumn{2}{|c|}{ Total } \\
\hline & $\mathbf{N}$ & $\%$ & $\mathbf{N}$ & $\%$ & $\mathbf{N}$ & $\%$ \\
\hline \multicolumn{7}{|l|}{ Place } \\
\hline Patio / backyard & 5 & 15.6 & 14 & 17.5 & 18 & 22.5 \\
\hline Kitchen & 0 & 0.0 & 12 & 15.0 & 12 & 15.0 \\
\hline Entry hall & 1 & 3.1 & 1 & 1.2 & 2 & 2.5 \\
\hline Bedroom & 5 & 15.6 & 12 & 15.0 & 17 & 21.3 \\
\hline Living room & 2 & 6.3 & 5 & 6.2 & 7 & 8.8 \\
\hline Bathroom & 6 & 18.7 & 12 & 15.0 & 18 & 22.5 \\
\hline Sidewalk & 2 & 6.3 & 11 & 13.8 & 13 & 16.3 \\
\hline Street / avenue & 9 & 28.1 & 8 & 10.0 & 17 & 21.3 \\
\hline Garden & 0 & 0.0 & 3 & 3.8 & 3 & 3.8 \\
\hline When getting into or out of vehicles & 2 & 6.3 & 2 & 2.5 & 4 & 5.0 \\
\hline \multicolumn{7}{|l|}{ Hospitalization } \\
\hline Yes & 4 & 16.0 & 6 & 10.9 & 10 & 12.5 \\
\hline No & 21 & 84.0 & 49 & 89.1 & 70 & 87.5 \\
\hline \multicolumn{7}{|l|}{ Type } \\
\hline Bed & 3 & 11.1 & 6 & 10.4 & 9 & 11.3 \\
\hline Chair or armchair & 2 & 7.4 & 1 & 1.7 & 3 & 3.8 \\
\hline Bath chair and/or toilet & 2 & 7.4 & 2 & 3.5 & 4 & 5.0 \\
\hline Own height & 20 & 74.1 & 47 & 81.0 & 67 & 83.8 \\
\hline Stairs & 0 & 0.0 & 1 & 1.7 & 1 & 1.3 \\
\hline Roof & 0 & 0.0 & 1 & 1.7 & 1 & 1.3 \\
\hline \multicolumn{7}{|l|}{ Consequences } \\
\hline Excoriations & 12 & 80.0 & 25 & 71.5 & 37 & 46.3 \\
\hline Wounds with stitches & 3 & 20.0 & 4 & 11.4 & 7 & 8.8 \\
\hline Closed fracture & 0 & 0.0 & 4 & 11.4 & 4 & 5.0 \\
\hline Sprain and strain & 0 & 0.0 & 2 & 5.7 & 2 & 2.5 \\
\hline
\end{tabular}

Among the intrinsic factors that caused falls in the elderly, the following stand out: $50 \%$, altered equilibrium; $30 \%$, muscle weakness; $28.8 \%$, dizziness/ vertigo; $25 \%$, difficulty to walk, among others. Among the extrinsic factors, the prevailing causes were: $26.3 \%$, slippery floors; $18.8 \%$, irregular floors or holes; $11.3 \%$, high step and/or uneven floor; $8.8 \%$, objects on the floor; $7.5 \%$, loose carpets, among others.

Falls can cause both physical and/or psychological consequences, among which several should be highlighted: $67.5 \%$ with the fear of falling again syndrome; $41.3 \%$ difficulties to walk; $25 \%$, anxiety;
$15 \%$ needed help with activities of daily living; $12.5 \%$, depression and $6.3 \%$, losses in decision making to organize one's own life.

As observed in Table 3, age is correlated with FIM, indicating that increased age is correlated with a lower FIM score. For age, the correlations are moderate and statistically significant. This was not the case for education, which was not correlated with FIM, as $p>$ 0.05 .

Table 4 reveals that no relation was found between elderly victims of falls with regard to gender and age.

Table 3 - Correlation coefficient between Functional Independence Measure and Instrumental Activities of Daily Living and age and education variables in elderly victims of falls living at home. Ribeirão Preto, SP, Brazil, 2011 ( $n=80$ )

\begin{tabular}{lccc}
\hline \multicolumn{1}{c}{ Variables } & Cognitive FIM & Motor FIM & Global FIM \\
\hline Age* $^{*}$ & -0.386 & -0.382 & -0.319 \\
Education & 0.266 & 0.251 & 0.238 \\
\hline
\end{tabular}

$* \mathrm{p}<0.01 . \mathrm{FIM}=$ Functional Independence Measure; IADL $=$ Instrumental Activities of Daily Living 
Table 4 - Logistic regression analysis, using the saturated model, of elderly fall victims according to gender and age. Ribeirão Preto-SP, Brazil, 2011

\begin{tabular}{lccc}
\hline \multirow{2}{*}{ Variables } & \multicolumn{2}{c}{$95 \%$ Confidence Interval } & Adjusted POR \\
\cline { 2 - 4 } & Lower Limit & Upper Limit & 0.724 \\
\hline Gender & 0.401 & 1.306 & 0.283 \\
Age (years) & 0.307 & 1.144 & 0.593 \\
\hline
\end{tabular}

$* \mathrm{p}<0.05$

\section{Discussion}

Data from 2010 indicate that approximately 424,000 people around the world die as a consequence of falls, $80 \%$ of which in low and middle-income countries; in addition, each year, 37.3 million elderly people are victims of falls and need medical care ${ }^{(12)}$.

The falls prevalence rate in this research corresponded to $33.3 \%$, higher than other research results $^{(13)}$ when compared with Brazilian ${ }^{(4)}$ and international(14-15) research, in which rates varied between 9.6 and $24.1 \%$.

In the epidemiology of falls, 0.7 falls/person/years is considered the average in the community, with an 0.2-1.6 interval(16). In this research, the media found was higher than literature findings.

Falls were prevalent among women between 60 and 79 years old. This result can be attributed to women's multiple tasks at home, making them more prone to injuries due to falls ${ }^{(16)}$. This frequency is not clear in the research yet, in view of different methods and distinct evaluation instruments.

The present research results are in line with data from the 2010 census, when the Brazilian Institute of Geography and Statistics (IBGE) registered more women and increased life expectancy, more enhanced in the female gender(17).

The most frequent falls were from the elderly's own height, in line with another study ${ }^{(18)}$. The consequences that were most identified for this type of fall were wounds, edemas, hematomas and/or excoriations and even fractures ${ }^{(15,18)}$.

Falls in the elderly are related with multiple intrinsic and extrinsic factors. Intrinsic aspects predominated over extrinsic ones in this research.

Among the intrinsic risk factors, the following are highlighted: use of different drugs, comorbidities and problems deriving from the aging process itself. In old age, decreased muscle strength can alter a person's balance, causing unstable walking. Besides, the presence of acute and chronic illnesses, like osteoporosis for example, and drug consumption can alter the cognitive status, enhancing the risk of falls(19).

Extrinsic factors ${ }^{(19)}$ are also common; these include environments with little light, loose carpets, stairs without sidebars, slippery floors, harsh climate (rain, hailstones, snow, ice) or inadequately arranged furniture, causing unsafe and dangerous environments for the elderly.

Domestic environments need to be adapted to minimize danger, besides the need for health promotion and disease and disability prevention in the elderly, with a view to decreasing fall risks.

Besides the physical limitations falls entail, the elderly are afraid of falling again. The fear falling syndrome is one of the main health problems and this condition entails physical, functional, psychological and social changes in this population's life, as described in an American study(20). In addition to these changes, in many cases, out of fear of falling again, the elderly limit their daily activities, such as daily tasks, leading to immobility and even causing social isolation, sadness and death.

In a Spanish study, involving 919 elderly people aged 65 years or older, $49.4 \%$ were afraid of falling, with higher rates among women and people over 75 years of age $^{(21)}$.

In a study on the quality of life of elderly community dwellers who were victims of falls, the authors underlined that $88.5 \%$ indicated fear of falling; $26.9 \%$ of them mentioned changes in basic activities of daily living, $23.1 \%$ modified habits and $19 \%$ immobilization ${ }^{(22)}$. The authors also emphasize the elderly fall victims experienced negative feelings, concentration and memory alterations, low self-esteem and altered body image.

Functional capacity evaluation studies do not report on the joint use of instruments like the FIM and instrumental activities of daily living scale. It should be highlighted that FIM data (motor FIM, cognitive FIM and global FIM) and Lawton and Brody's IADL scale in this study show statistical significance $(p<0.01)$ with regard to age. 
The elderly population is rapidly increasing, especially in the group over 80 years of age. This is the population that most progresses what functional disability is concerned, which demands greater care and, hence, higher costs for society. This elderly health condition is not measured by the presence or not of diseases, but by the extent to which functional capacity is maintained(23). The increased care demand functional disability can create demands greater training and preparation from professionals active in elderly care delivery, especially nurses, with a view to health promotion and chronic degenerative disease prevention and rehabilitation, and also appoints the need to formulate and structure preventive actions for social, cognitive and physical $\operatorname{aspects}^{(24)}$

In another evaluation study that used Katz' Index and Lawton and Brody's Scale, involving 73 elderly fall victims living in the community, a drop in their functional capacity to perform instrumental activities of daily living was verified and, consequently, a loss of independence, autonomy and quality of life(7).

It was evidenced that falls cause a decrease in the elderly's functional capacity, considering functional independence as well as instrumental activities of daily living, making them more dependent in this respect. Also, the older the elderly, the more compromised their capacity will be to accomplish routine activities.

The elderly's main problem can be the loss of physical skills to perform different activities. Therefore, all health actions should aim to promote healthy aging and functional capacity maintenance(25).

Thus, falls need to be prevented in the elderly, considering that they can directly interfere in their functional capacity, also furthering psychological alterations as a result of their problems to accomplish their activities.

\section{Conclusions}

The prevalence of falls in this study corresponded to $33.3 \%$. While assessing functional independence with the help of the FIM (motor FIM, cognitive FIM and global FIM) and Lawton and Brody's scale, a correlation was found between elderly fall victims and the age variable, and significant changes were identified in the level of independence to accomplish activities of daily living.

The main goal in gerontology, in elderly care, is to maintain their independence and autonomy for basic activities of daily living, which may be directly related with their quality of life.
Knowing whether the fall can interfere in the elderly's functional capacity and how this happens, i.e. whether the fall can modify the way they develop their basic activities and instrumental activities of daily living, can be a predictive factor of this population's quality of life. It can also indicate the extent to which these people will need help after falling to accomplish their activities, as well as identify which elderly are able to live alone.

The information these findings contain are very important for a better understanding of this phenomenon, alerting professionals who work with elderly people and policy makers about the need for further attention to falls prevention measures and training them for specific care delivery to these elderly, minimizing the consequences of falls.

When treating a consequence of a fall, professionals need to look not only at the physical sequelae, but also, among others, at how much the fall can interfere in the elderly's daily activities. As from the first attendance, the dimension of the event needs to be evaluated, the extent to which it interfered and can interfere in the person's functional capacity. The earlier disabilities deriving from falls are treated, the more severe complications can be avoided. Maintaining the elderly's functional capacity is directly related with his capacity to perform enjoyable activities, even at more advanced aged, extending their autonomy and independence as long as possible.

Finally, one important factor that should be highlighted and is part of the proposal for future research is the need to invest in further studies that apply preventive measures to this population and quantify whether they are truly effective to prevent falls, keeping in mind that the paradigm of the functional capacity concept also direct the elderly health concept.

\section{References}

1. Instituto Brasileiro de Geografia e Estatística - IBGE. Indicadores sociodemográficos e de saúde no Brasil. 2009. [acesso 7 jul 2011]. Disponível em: http:// www.ibge.gov.br/home/estatistica/populacao/indic sociosaude/2009/indicsaude.pdf.

2. Silva MJ, Lopes MVO, Araujo MFM, Morales GLA. Avaliação do grau de dependência nas atividade da vida diária em idosos da cidade de Fortaleza - Ceará. Acta Paul Enferm. 2006;19(2):201-6.

3. Fiedler MM, Peres KG. Capacidade funcional e fatores associados em idosos do Sul do Brasil: um estudo de base populacional. Cad Saúde Pública. 2008;24(2):409-15. 
4. Fabrício, S.C.C., Rodrigues, R.A.P.; Costa, M.L.J.. Falls among older adults seen at a São Paulo State public hospital: causes and consequences. Rev Saúde Pública 2004;38(1):93-9.

5.Aguiar CF, Assis M. Perfil de mulheres idosas segundo a ocorrência de quedas: estudo de demanda no Núcleo de Atenção ao idoso da UNATI/UERJ. Rev Bras Geriatr Gerontol. 2009;12(3):391-404.

6. Organización Mundial de Salud (OMS). Caídas, nota descriptiva n 344. 2010. [acesso 24 fev 2011] Disponível em: http://www.who.int/mediacentre/ factsheets/fs344/es/.

7. Jahana KO, Diogo MJDE. Quedas em idosos: principais causas e consequências. Cienc Saúde Colet. 2007;4(17):148-53.

8. Zecevic AA, Salmoni AW, Speechley M, Vandervoort AA. Defining a fall an reason for falling: comparisons among the views of seniors, health care providers, and the research literature. Gerontologist. 2006;46(3):367-76.

9. Bertolucci PH, Brucki SM, Campacci SR, Juliano Y. O Mini-Exame do Estado Mental em uma população geral: impacto da escolaridade. Arq Neuropsiquiatr. 1994;52(1):1-7.

10. Santos RL, Virtuoso Jr JS. Confiabilidade da versão brasileira da escala de atividades instrumentais da vida diária. RBPS. 2008;21(4):290-6.

11. Riberto M, Miyazaki MH, Jucá SSH, Sakamoto $H$, Potiguara $P$, Pinto N. Validação da versão brasileira da medida de independência funcional. Acta Fisiatr. 2004;11(2):72-6.

12. Organización Mundial de Salud (OMS). Estrategia mundial sobre régimen alimentario, actividad física y salud. 2010. [acesso 24 fev 2011]. Disponível em: http://www.who.int/dietphysicalactivity/factsheet_ myths/es/

13. Moreira MD, Costa AR, Felipe LR, Caldas CP. The association between nursing diagnoses and the occurrence of falls observed among elderly individuals assisted in an outpatient facility. Rev. Latino-Am. Enfermagem. 2007;15(2):311-7.

14. Shin $K R$, Kang $Y$, Hwang $E H$, Jung $D$. The prevalence, characteristics and correlates of falls in Korean community-dwelling older adults. Int Nurs Rev. 2009;56(3):387-92.

15. Boyd R, Stevens JA. Falls and fear of falling: burden, beliefs and behaviours. Age Ageing. 2009;38(4):423-8. 16. Rubenstein LZ, Josephson KR. The epidemiology of falls and syncope. Clin Geriatr Med. 2002;18(2):141-58.
17. Instituto Brasileiro de Geografia e Estatística - IBGE. Censo demográfico 2010. [acesso 2 jun 2011]. Disponível em: http://www.ibge.gov.br/home/ estatistica/populacao/censo2010/default.shtm.

18. Gonzáles CG, Marín LPP, Pereira ZG. Características de las caídas en el adulto mayor que vive en la comunidad. Rev Méd Chile. 2001;129(9):1021-30.

19. Czerwinski E, Kimorek A, Milert A, Borowy P. Causes of falls in women in Krakow population. Ortop Traumatol Rehabil. 2008;10(5):429-40.

20. Scheffer AC, Shuurmans MJ, Dijk NV, Hooft TVD, Rooij SE. Fear of falling: measurement strategy, prevalence, risk factors and consequences among older people. Age Ageing. 2008;37(1):19-24.

21. Martínez IP, Bravo BN, Pretel FA, Muñoz JND, Molina RPE, Hidalgo JL. Miedo a las caídas en las personas mayores no institucionalizadas. Gac Sanit. $2010 ; 24(6): 453-9$.

22. Ribeiro AP, Souza ER, Atie S, Souza AC, Schilithz AO. $A$ influência das quedas na qualidade de vida de idosos. Ciênc Saúde Coletiva. 2008;13(4):1264-73.

23. Bonardi G, Souza VBA, Moraes JFD. Incapacidade funcional e idosos: Um desafio para os profissionais de saúde. Sci Med. 2007;17(3):138-44.

24. Pilger $\mathrm{C}$, Menon $\mathrm{MH}$, Mathias TAF. Características sociodemográficas e de saúde de idosos: contribuições para os serviços de saúde. Rev. Latino-Am. Enfermagem [periódico na Internet]. set-out 2011 [acesso 07 ago 2012];19(5):[09 telas]. Disponível em: http://www. scielo.br/pdf/rlae/v19n5/pt_22.pdf.

25. Portaria no 2.528 de 19 de Outubro de 2006 (BR). Aprova a Política Nacional de Saúde da Pessoa Idosa. Brasília; 2006 